\title{
Addressing Misconceptions about Wildland-Urban Interface Issues 1
}

Martha C. Monroe ${ }^{2}$

Audiences can fail to understand a message for a variety of reasons, despite the most scintillating and relevant presentation. A good communicator looks for clues that will help him or her revise or repair the presentation. One particular challenge to understanding a message is typical of science-based communication efforts and deserves special attention.

Audiences often come to a presentation or program with previous ideas about the issue. If their ideas involve basic misconceptions (also called pre-existing bias, naive theories, and misperceptions), educators believe new information will not be understood because it conflicts with the understanding the audience already has (Berliner 1987). These misconceptions occur at the foundation of understanding and may be difficult to identify. Much of the research about misconceptions is in physics, where ideas about the distance from the earth and sun and the tilt of the earth's axis, for example, change how people understand the seasons. It often takes lengthy interviews to identify clearly the misconception.
Residents in the wildland-urban interface probably have some notions about their local environment. They may have an experience, or may have heard something from neighbors, which helps them construct explanations and understandings that make sense to them. The challenge for extension agents and resource managers is to understand the beliefs that are interfering with the acceptance of new concepts, acknowledge them, show how they are incomplete, and help people restructure their mental models to accommodate the new information. Educators have to do this all the time, but it is a new technique for extension agents and resource managers. While it may be easiest to address misconceptions when speaking to an individual, it is important to consider how to use this concept when speaking to a group, when writing a newsletter article, or when talking to the media.

\section{An Example}

Consider the process of explaining the value of defensible space to reduce the risk of wildfire. The extension agent or forester might explain that a cleared area of just 30 feet around a home will help

1. This document is FOR 108, one of a series of the School of Forest Resources and Conservation, Florida Cooperative Extension Service, Institute of Food and Agricultural Sciences, University of Florida. First published November 2005. This document was produced in cooperation with the Southern Center for Wildland-Urban Interface Research and Information, USDA Forest Service. Please visit the EDIS Web site at http://edis.ifas.ufl.edu.

2. Martha C. Monroe, Associate Professor, School of Forest Resources and Conservation, Cooperative Extension Service, Institute of Food and Agricultural Sciences, University of Florida, Gainesville, FL 32611.

The Institute of Food and Agricultural Sciences (IFAS) is an Equal Opportunity Institution authorized to provide research, educational information and other services only to individuals and institutions that function with non-discrimination with respect to race, creed, color, religion, age, disability, sex, sexual orientation, marital status, national origin, political opinions or affiliations. U.S. Department of Agriculture, Cooperative Extension Service, University of Florida, IFAS, Florida A. \& M. University Cooperative Extension Program, and Boards of County Commissioners Cooperating. Larry Arrington, Dean 
protect it from wildfire and demonstrate how vegetation can be managed within that zone. The homeowner knows that a wildfire can send sparks and embers ahead of fire; in fact he/she knows where a fire jumped across a 6-lane highway. In her mind, protecting a house from wildfire means keeping the fire away from her house. In her mind, this can only be done by removing all vegetation that could bring a fire close enough to send sparks to her home. Because 30 feet is clearly not sufficient, defensible space will not work. She would have to clear 200 feet around her home and that would not be attractive. She stops listening to the information, since the agent obviously does not know enough.

The extension agent who realizes that the homeowner is not listening could ask a few questions:

Do you think 30 feet of managed vegetation is not enough to help protect your house? What do you think would be necessary to keep your house from igniting?

Ideally the discussion that follows will help the agent realize there is a basic misconception about fire behavior and what constitutes "protecting your house." The next time he/she explains defensible space, it might go differently. First, he/she would acknowledge the common understanding:

We can't really stop a wildfire once it gets going; it can travel quickly and jump large distances. It will continue until it runs out of fuel or the weather changes. It would seem that our best chance to save a house would be to remove all fuel that could bring a fire near.

After acknowledging the prior understanding, the agent introduces a new way of looking at the problem. He/she uses analogies and simple explanations without the jargon of his/her profession.

But most people don't want to live in a parking lot, and we can accomplish the goal of saving the house without removing that much vegetation. Three things can set a house on fire: (1) sparks that land on needles in the gutter or other nearby flammable material, (2) direct flames from shrubs or bushes close to the house, or (3) intense heat from burning vegetation that causes the house to burst into flames.
This process would take several minutes. You've probably seen this happen when coals suddenly flame up when a new log is placed on the fire.

So protecting a house means cleaning up the dead and flammable material, keeping the flames away from the home, and reducing nearby vegetation so the fire's heat is not close enough to ignite the house. Most wildfires will burn up fine fuels in less than 1 minute and move on. If there isn't any fuel close to the house, the fire won't stay long enough to get the house hot enough to burn.

You can help protect your house by creating defensible space. This is the area about 30 feet from your home that has less dense vegetation and no piles of needles and branches. This space also allows us to get our vehicles close enough to lend assistance, and gives us room to maneuver.

One has to be careful in how this explanation is constructed. People often consider their landscape to be part of their home, so they think defensible space will protect more than their house. The idea that their forest can burn and their house survive is foreign to most homeowners. They are most familiar with an urban house fire, where flames consume a structure unless the fire is extinguished. To help them accept your solution of defensible space, you can help homeowners change their ideas of house fires to those of wildfires; help them gain a little more information about wildfire behavior. They'll be better able to understand that process through analogies which challenge their preconceived notions of wildfire.

A good communicator must balance the conversation with care. On the one hand, she or he recognizes the resident has a basic misconception that is undermining the message. On the other hand, she or he must continue to listen to the resident in case this is not the problem and the resident has some important new ideas to share. Most communicators need some time to think about how to identify, understand, and address misconceptions. It may be helpful to interact with experts who recognize when people do not understand their information but may not have determined how best to explain it. 


\section{The Process}

The process of communicating when the audience has a different (and conflicting) understanding of the issue can be broken down into several steps (Berliner 1987; Dunwoody 2003):

1. Acknowledge the plausibility of the individual's existing belief, e.g., "I can see how you might think that..."

2. Provide easily understood examples that demonstrate that the belief is not always valid.

3. Introduce the "theory" intended to replace the belief.

4. Provide examples that demonstrate the successful operation of the new theory.

Before communicators can use these four steps, however, they must first recognize whether the communication difficulty is due to a misunderstanding. This may only be possible through conversations, questioning, and careful listening. One clue is when people say that they don't believe your advice. Another is when they explain the experience that leads them to a different conclusion. They might even ask a question that reveals the misunderstanding, "How can defensible space do any good when wildfires jump across the interstate?"

The second challenge is to continue the conversation with the audience to reveal the assumptions they are making that drive their understanding of the situation. The question above focuses on the distance of defensible space when the root of the misconception is the difference between a fire coming close to their house and preventing it from staying near their house. What they ask may not reveal the misconception that prevents them from accepting the new information. Additional questions and probing are necessary. If the manager responds to the first statements by explaining why 30 feet may be sufficient, the homeowner may eventually say, "Oh you mean the fire will still burn my woods?" That proclamation announces the misconception at the root of the communication difficulty.
The third challenge is to explain how the new information requires a different perspective. Analogies can be helpful here, but they aren't likely to spring to mind immediately. It will help to have some strategies readily available for dealing with common misunderstandings.

Table 1 provides some examples of typical conversations that include misconceptions in the wildland-urban interface and some strategies for overcoming them. The first column describes what the communicator wishes to convey and the second describes how the audience often reacts. If communication continues, the misconception in the third column may be revealed. The fourth column provides an example of what the communicator ought to say in the recommended four steps.

\section{Summary}

As the world becomes more technical and complex, the public looks to extension agents and natural resource specialists for information. In the process of providing that information, we need to recognize that the information already in their heads might conflict with the information we are providing. Engaging the audience in a conversation can help communicators know where misunderstandings might prevent them from accepting new information.

The examples provided here demonstrate that it is easy for residents to discount a natural resource message because it does not correspond with what they know. Although some of these examples may not ring true in your area because of cultural differences or individual experience, they represent the types of misconceptions that can get in the way of productive communication. For some people, a prior belief may give them pause. They may become confused, ask a question, or begin to ignore the message. If you want to be believed, you need to walk them through an explanation that recognizes what they are thinking and then gives them reasons to understand it from your perspective.

\section{References}

Berliner, D. 1987. How do we tackle kids' science misconceptions? Instructor 97:4 Nov/Dec. (14-15). 
Dunwoody, S. 2003. Presentation delivered at

Florida Museum of Natural History, November 2003, Gainesville Florida.

Table 1. Recognizing Interface Misconceptions and Changing Them

\begin{tabular}{|c|c|c|c|}
\hline Your message & Audience Thinks & $\begin{array}{l}\text { The Underlying } \\
\text { Misconception }\end{array}$ & You might say... \\
\hline $\begin{array}{l}\text { Radon is a } \\
\text { possible health } \\
\text { threat, so test } \\
\text { your home for } \\
\text { radon. }\end{array}$ & $\begin{array}{l}\text { I have never } \\
\text { gotten sick from } \\
\text { trips to my } \\
\text { basement. If we } \\
\text { have radon, it } \\
\text { can't be a health } \\
\text { threat. }\end{array}$ & $\begin{array}{l}\text { Anything natural } \\
\text { is good; harmful } \\
\text { radiation only } \\
\text { comes from } \\
\text { nuclear power } \\
\text { plants, bombs, } \\
\text { and X rays. } \\
\text { Radon is not a } \\
\text { health threat. }\end{array}$ & $\begin{array}{l}\text { I know it is hard to believe that a chemical in the earth can be dangerous. } \\
\text { But many natural elements can be harmful to us, like asbestos and } \\
\text { arsenic. And like other forms of chemical contamination, we aren't likely } \\
\text { to see evidence of a problem right away. But like other health issues, } \\
\text { prevention is easier than cure, so testing for radon in your home is a } \\
\text { good idea. Here is a map of where we have found radon in this area. } \\
\text { Here is where we are now. This is a test kit. Let's use it together. }\end{array}$ \\
\hline $\begin{array}{l}\text { Outdoor cats are } \\
\text { non-native } \\
\text { animals that can } \\
\text { do serious } \\
\text { damage to local } \\
\text { ecosystems so } \\
\text { should be kept } \\
\text { indoors. }\end{array}$ & $\begin{array}{l}\text { My cat won't kill } \\
\text { anything; I feed } \\
\text { it plenty of food. }\end{array}$ & $\begin{array}{l}\text { Cats deserve to } \\
\text { go outside } \\
\text { where they } \\
\text { co-exist with the } \\
\text { local wildlife. }\end{array}$ & $\begin{array}{l}\text { I am sure you take good care of your cat and feed it adequately. Does } \\
\text { your cat pay attention to birds through the window? Does your cat stalk } \\
\text { and pounce on toys? Chasing and catching are instinctive traits. Cats } \\
\text { don't need to be hungry to pounce on a toy or a small bird. Cats can live } \\
\text { happily indoors. }\end{array}$ \\
\hline $\begin{array}{l}\text { Remove tallow } \\
\text { trees from your } \\
\text { yard. }\end{array}$ & $\begin{array}{l}\text { I like my tallow } \\
\text { tree. It provides } \\
\text { good shade and } \\
\text { enhances my } \\
\text { yard. }\end{array}$ & $\begin{array}{l}\text { A single tree in } \\
\text { my yard cannot } \\
\text { harm anything. }\end{array}$ & $\begin{array}{l}\text { It is hard to imagine how quickly populations expand. Just one pregnant } \\
\text { rabbit on an island can generate enough offspring over several } \\
\text { generations to strip completely the island of vegetation. Tallow trees } \\
\text { begin producing viable seed after only } 3 \text { years. They can spread by root } \\
\text { fragments and cuttings, so are quick to invade after a hurricane. Just one } \\
\text { tallow tree can produce } 100,000 \text { seeds every year. Nearly all of these } \\
\text { seeds are viable and can germinate even after several years. A mature } \\
\text { stand can produce } 4,500 \text { kg of seeds per hectare per year. Trees remain } \\
\text { productive for } 100 \text { years. Even one tallow tree presents a danger of } \\
\text { explosive expansion that can hurt local ecosystems. }\end{array}$ \\
\hline $\begin{array}{l}\text { Clearcutting is } \\
\text { the first step in } \\
\text { creating a } \\
\text { healthy, } \\
\text { productive forest } \\
\text { system. }\end{array}$ & $\begin{array}{l}\text { I like to see } \\
\text { trees in the } \\
\text { forest. The } \\
\text { animals need a } \\
\text { home. }\end{array}$ & $\begin{array}{l}\text { Clearcutting } \\
\text { destroys the } \\
\text { forest. It will } \\
\text { never be a } \\
\text { forest again. }\end{array}$ & $\begin{array}{l}\text { There are plenty of cases where land clearing results in building homes } \\
\text { and offices instead of replanting a forest. That is when removing the trees } \\
\text { destroys the forest. In this forest, however, this landowner plans to keep } \\
\text { her land managed as a working forest. By keeping the harvest areas } \\
\text { small, wildlife like turkey and deer can move to other areas of the forest. } \\
\text { The trees and the hunting leases represent a steady income. This } \\
\text { landowner is motivated to follow the best practices for keeping the forest } \\
\text { and wildlife healthy. Clearcutting is good for some animals, enables new } \\
\text { seedlings to grow in full sunlight, and keeps the landowner from selling to } \\
\text { development. }\end{array}$ \\
\hline
\end{tabular}

